\title{
Status of pelicans and cormorants on the northern Black Sea
}

\author{
I. SCHOGOLEV, A. RUDENKO and A.J. CRIVELLI*
}

\section{Summary}

The status of breeding pelicans and cormorants is assessed in the area from the Danube delta (Romania) to the northern part of the Crimean peninsula. Four breeding species occur in inland and coastal wetlands: Dalmatian Pelican Pelecanus crispus, Great White Pelican Pelecanus onocrotalus, Great Cormorant Phalacrocorax carbo and Pygmy Cormorant Phalacrocorax pygmeus. Data on clutch size and breeding success are given. Historically, all four species were restricted to the Danube delta. Currently, with the exception of Dalmatian Pelican, they all breed successfully on the eastern Black Sea coast in the Ukraine. There are many conservation problems that will jeopardize the breeding of these species in the future if nothing is done.

\section{Introduction}

The Black Sea and the major rivers (Danube, Dnestr, Dnepr) draining into it have experienced 30 years of catastrophic ecological damage as the result of dam-building, industrial pollution, overfishing, eutrophication, habitat destruction and reduction in annual discharge of the major rivers (Mee 1992, Pringle et al. 1993, Navodaru et al. 2001). Such changes might have several impacts on populations of waterbird, such as fish-eating birds breeding on the Black Sea coast, in coastal lagoons and in river deltas.

Waterbird investigations within this region have been conducted mainly on large breeding colonies of gulls and terns (Rudenko 1996) and wading birds (Schogolev 1996, Marinov and Hulea 1996), but the status and the trend of cormorants and pelicans, all strict piscivores, remains poorly known in this region. The four species breeding in this region are Dalmatian Pelican Pelecanus crispus, Great White Pelican Pelecanus onocrotalus, Great Cormorant Phalacrocorax carbo and Pygmy Cormorant Phalacrocorax pygmeus. Dalmatian Pelican and Pygmy Cormorant are included in the 2002 IUCN list of threatened species as Near Threatened. Great White Pelican within the Palearctic region should also be considered as Near Threatened (Crivelli et al. 2000a). These birds have been and are still persecuted by fishermen who see them as competitors for fish resources. For example, during the period 1949 to 1970 in the Danube delta, bounties were given for pelicans and cormorants killed, and often breeding colonies were totally destroyed.

The aims of this paper were threefold: (I) to assess the status of cormorants and pelicans within the study area; (2) to try to obtain some biological data with an emphasis on the two species of cormorant; and (3) to identify the conservation problems for these birds. 


\section{Study area and methods}

Within the study area there are many brackish lagoon systems (e.g. Saski lagoon, $200 \mathrm{~km}^{2}$; Budaki lagoon, $28 \mathrm{~km}^{2}$ ) and three major river deltas: the Danube delta $\left(680 \mathrm{~km}^{2}\right)$ in Romania and Ukraine, the Dnestr delta $\left(220 \mathrm{~km}^{2}\right)$ and the Dnepr delta $\left(330 \mathrm{~km}^{2}\right)$, both in the Ukraine. In the vicinity of these latter two, $1,072 \mathrm{~km}^{2}$ are covered by freshwater wetlands.

Surveys of breeding colonies of Pelecaniformes on the Black Sea coast of the Ukraine were carried out from 1995 to 2001 from the Danube delta to the northern part of the Crimean peninsula. Data on clutch size and breeding success of both species of cormorants were collected only in the Danube and Dnestr River deltas and in the Black Sea Reserve $\left(46.30^{\circ} \mathrm{N} 32.30^{\circ} \mathrm{E}\right)$ from 1998 to 2001 (Figure 1 ).

From early April to late June, all the wetlands located in the study area were visited to locate any bird colonies. When a cormorant or pelican colony was found, active nests (with at least one egg and/or chick) were counted from a boat or by walking in the flooded area. Clutch size was usually estimated in the third week of incubation; however, this was only done occasionally and on a subsample of nests to avoid disturbing the whole colony. Breeding success was assessed when chicks were about 20 days old for cormorants and older for pelicans.

\section{Results and discussion}

\section{Dalmatian Pelican}

Dalmatian Pelican was formerly known to breed in the Romanian (Crivelli and Vizi 1981, Crivelli et al. 1991) and Ukrainian (Lysenko 1994) parts of the Danube delta and

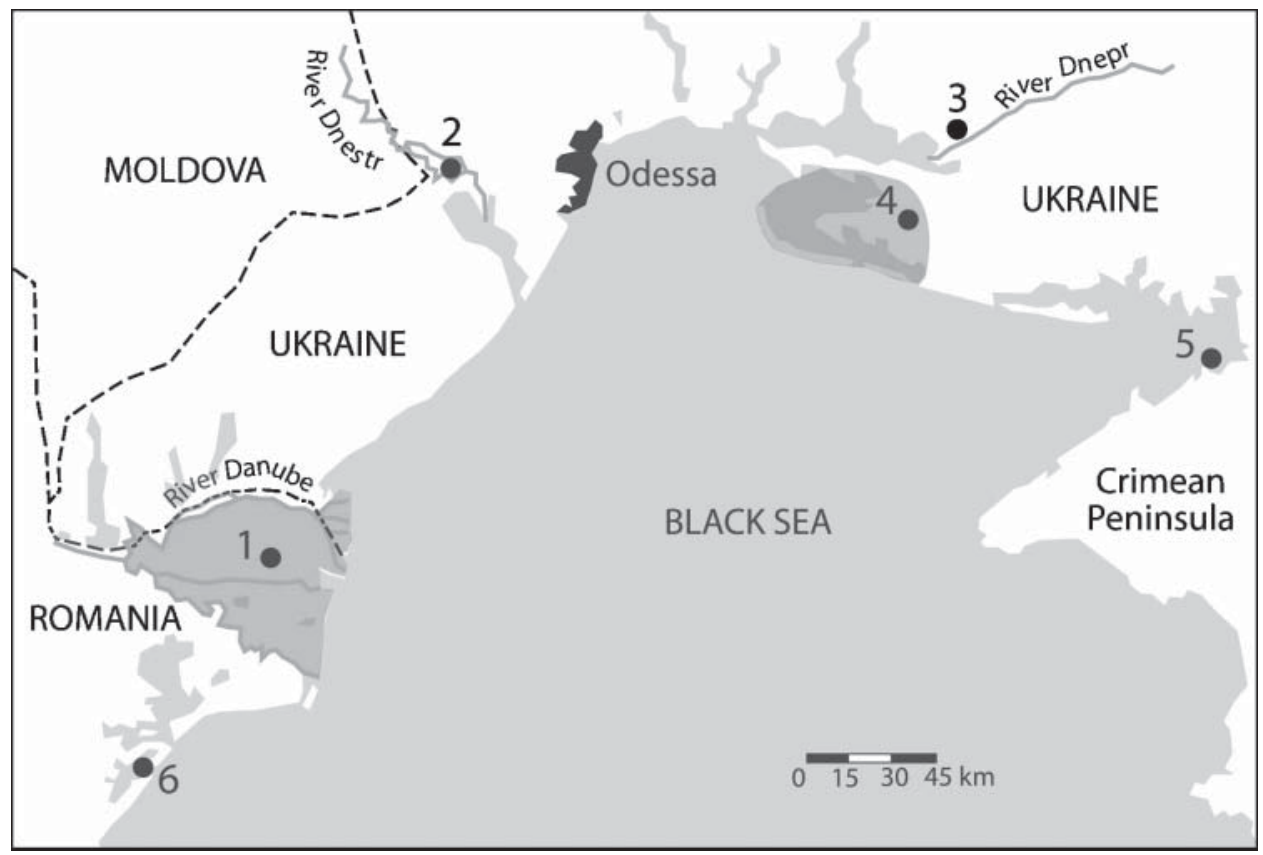

Figure 1. The Black Sea coast from the Danube delta to the northern part of the Crimean peninsula. 1, Danube delta; 2, Dnestr delta; 3, Dnepr delta; 4, Black Sea Reserve; 5, Lebaizi island; 6, Sinoe lagoon. 
up to 1940 also in the Dnestr delta, Azov Sea and other places (Lysenko 1994). From 1997 to 2001, the species was found breeding only in the Romanian part of the Danube delta. This species usually has scattered breeding colonies that are quite difficult to find; our estimates of breeding numbers are therefore minimum figures. In 1997, 60 nests were counted in four locations, two of them being at the apex of the delta, 24 nests at Merheiu Lake, the largest colony (30 nests) being at the Sinoe lagoon south of the Danube delta. In 1998, there were more than 100 successful nests at the Sinoe lagoon ( 125 large chicks observed). In 1999, 60-70 active nests were estimated at Sinoe lagoon and no other colony was found. No estimate is available for 2000. In 2001, about 6o birds started incubation at the Sinoe lagoon, but the colony was destroyed by waves in mid-April. Platteeuw et al. (2000-2001) found 400 pairs at Lake Lejai, a surprisingly high figure for this species in the Danube delta, which could be explained by the fact that this estimate was made by aerial survey.

Because our estimates are based only on one visit and the other available estimates are by aerial survey, none of them is satisfactory. Aerial surveying is a census methodology inappropriate for pelicans and systematically overestimates breeding numbers, as it is not possible to distinguish between breeding and non-breeding birds. Only ground visits made three times during the breeding season give reliable figures (Crivelli et al. 1998). The current number of breeding pairs of Dalmatian Pelicans within the Danube delta is estimated at about 200-250 pairs. Although some colonies are well protected because they are inaccessible (e.g. Lake Lejai), others like the Sinoe lagoon encounter major conservation problems due to repeated destruction of the pelican and cormorant colonies by fishermen, and by waves during thunderstorms. Either the building of artificial rafts (Catsadorakis and Crivelli 200I) or the restoration of the islands used, accompanied by efficient wardening, would ensure the future of the Sinoe lagoon breeding colony.

\section{Great White Pelican}

Great White Pelican has been known to breed within the Romanian part of the Danube delta for 100 years (Ambruster 1879) and according to a review on pelican status within the Palearctic there were 3,000-3,500 breeding pairs nest in the 1990s, always at Merheiu Lake (Crivelli et al. 1991). However, in 1996, only 1,800 pairs were estimated. In 1997, 2,000 \pm 300 nests were estimated at Merheiu Lake. No data were available for 1998. In 1999, for the first time, the number of nests was counted one by one, and only $460 \pm 30$ active nests were found although $4,500 \pm 500$ birds with adult plumage were counted within the delta; thus only $20 \%$ were actually breeding. No estimate was available for 2000. In 2001, 1,700 \pm 150 nests were counted with a total of $6,900 \pm 500$ breeding and non-breeding birds within the Danube delta, of which $50 \%$ were breeding. A more conservative figure than the above estimated by plane and by ground surveys gave 3,500 pairs (Platteeuw et al. 2000-2001).

From individual marking, we know that this species does not breed before it is 3 years old (Crivelli and Hatzilacou, unpubl. data). However, at 2 years old, the birds look like adults, the only difference during breeding being the absence of a knob in non-breeding birds. One way to make more accurate estimates of the number of breeding pairs of this species at Merheiu Lake without entering the colony would be to count from a hide the number of pelicans with a knob three times in May, the main laying period. In 2001, 320 nests were abandoned after the visit to the colony by 
Austrian tourists, brought there by a fisherman. The disturbance by tourists visiting the Great White Pelican colony at Merheiu Lake has increased dramatically in the last few years because of the construction of hotels (on Lake Matitsa and at Murigel) not far from this colony.

Formerly this species was rarely observed in the Ukraine, and it is only since the middle of the 1980s that regular flocks have occurred in spring and autumn. This increase continued in the 1990s with a maximum of 4,000 birds in 2001, most being non-breeding birds. In 1995 the first attempted nesting since 1907 occurred in the Ukraine within the Black Sea Reserve (Yaremchenko and Rudenko 1997, Ardamatskaya 1994). Since then, within the reserve, breeding has been recorded annually mainly on Orlov island, the number of active nests being between five and 343 (2000) depending on year. The birds lay one to three eggs per nest from early May onward; the mean clutch size was 1.8 eggs from 1995 to 1997 and 2.0 eggs from 1999 to 2001 . However, in 1995, 1996, 1997 and 1998 the breeding failed totally. In 1999, 2000 and 2001 the breeding success (chicks fledged per active nest) was 0.9-1.0, 0.2 and 0.03 respectively. Breeding success can be low because of flooding, predation by gulls or destruction of the nests by fishermen, a consequence of a lack of wardening. Outside the reserve, in 1999, 46 Great White Pelican nests with eggs were found in mid-June on the sandy island of Lebiazi in north-western Crimea (Figure1, site 5). In 2000 and 2002 they again laid eggs there, but the nests were destroyed by fishermen (N. Tarina, pers. comm.). In 2001, no colony was found there. Each time this pelican has bred in the Ukraine on bare sandy islands they were associated with cormorant nests.

In conclusion, Dalmatian Pelican breeds only within the Romanian part of the Danube delta, with a low breeding success. Great White Pelican also formerly bred only within the Romanian part of the Danube delta, but since the mid-1990s it has bred in increasing numbers in the Ukraine. There is possibly a shift from the Danube delta to Ukraine, which might be explained by the deteriorating situation of fish resources and the recent abandonment of extensive aquaculture within the Danube delta forcing the Great White Pelicans to use new areas for foraging. Within the study area, disturbance and destruction of breeding colonies are the main threats jeopardizing the fate of both species in this part of the Black Sea coast.

\section{Great Cormorant}

Great Cormorants have increased in south-eastern Europe (Catsadorakis et al. 1996, Schogolev 1996) as elsewhere in Europe (Van Eerden and Gregersen 1995, Keller et al. 2003). Increases in our study area have been observed since the 1980s-1990s (Figure 2). In the Dnestr and Dnepr deltas, they breed on trees Salix alba and shrubs Salix cinerea though in the Black Sea Reserve, on Lebiazi island and in the Sinoe lagoon they breed primarily on bare sandy islands. In the Danube delta, the problem of estimating the total number of breeding pairs is complex, because colonies are scattered and often move from one year to the next. This might explain the discrepancies between our counts (1994-2001: 5,000-7,000 breeding pairs), those from Marinov and Hulea (1996 and pers. comm.; 1994: 6,900, 1997: 13,412 breeding pairs), and an estimate made by aerial survey by Platteeuw et al. (2000-2001; 14,150 breeding pairs in 2001). At Lebiazi island, 580 nests were counted in 1997 and 900 in 1999. 


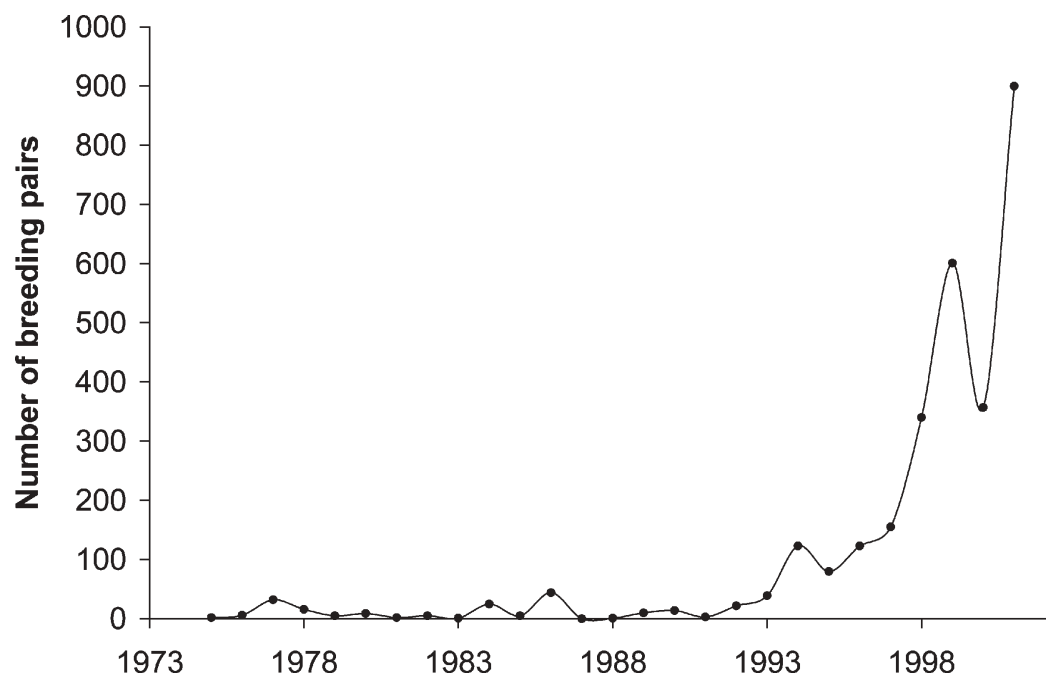

Figure 2. Trends in numbers of breeding pairs of Great Cormorant in the Dnestr delta and in the Black Sea Reserve, Ukraine, 1972-2001.

After a sharp increase in breeding numbers in the period 1983-1993, the number of breeding pairs from the Danube delta to the Crimean peninsula has stabilized from 1994 to 2001 at C. $11,000-13,000$.

Clutch sizes in 1998, 1999 and 2001 within the Black Sea Reserve were 3.35 eggs ( $\mathrm{SE}=1.05, n=136$, range $1-5$ eggs), 3.67 eggs ( $\mathrm{SE}=0.89, n=90$, range $2-5$ eggs) and 3.37 eggs ( $\mathrm{SE}=0.86, n=317$, range $2-6$ eggs), respectively. At Lebiazi island, the clutch size was 3.50 eggs ( $\mathrm{SE}=0.67, n=117$, range $2-5$ eggs). The breeding success of cormorant is higher in the Dnestr delta and in the Black Sea Reserve than in the Danube delta (Table 1 ). These differences might be explained by less disturbance and less destruction of nests by wind and fishermen in the Dnestr than in the two other sites.

Table 1. Breeding success (BS) of Great Cormorant in the Dnestr and Danube deltas and in the Black Sea Reserve.

\begin{tabular}{|c|c|c|c|c|c|c|c|c|c|}
\hline \multirow[t]{2}{*}{ Year } & \multicolumn{3}{|l|}{ Dnestr } & \multicolumn{3}{|l|}{ Danube } & \multicolumn{3}{|c|}{ Black Sea Reserve } \\
\hline & $\mathrm{BS}^{\mathrm{a}}(\mathrm{SE})$ & $\begin{array}{l}\text { No. of } \\
\text { nests }\end{array}$ & Range & $\mathrm{BS}^{\mathrm{a}}(\mathrm{SE})$ & $\begin{array}{l}\text { No. of } \\
\text { nests }\end{array}$ & Range & $\mathrm{BS}^{\mathrm{a}}(\mathrm{SE})$ & $\begin{array}{l}\text { No. of } \\
\text { nests }\end{array}$ & Range \\
\hline 1998 & $\begin{array}{l}3.18 \\
(0.58)\end{array}$ & 177 & $2-5$ chicks & - & - & - & $\begin{array}{l}3.34 \\
(1.09)\end{array}$ & 44 & 1-5 chicks \\
\hline 1999 & $\begin{array}{l}3.51 \\
(0.63)\end{array}$ & 161 & $2-5$ chicks & $\begin{array}{l}2.60 \\
(0.71)\end{array}$ & 111 & $\begin{array}{l}1-4 \\
\text { chicks }\end{array}$ & $\begin{array}{l}3.87 \\
(0.68)\end{array}$ & 76 & 2-5 chicks \\
\hline 2000 & $\begin{array}{l}3.06 \\
(0.47)\end{array}$ & 144 & 2-4 chicks & - & - & - & $\begin{array}{l}3.63 \\
(0.77)\end{array}$ & 112 & 1-5 chicks \\
\hline 2001 & $\begin{array}{l}2.60 \\
(0.56)\end{array}$ & 383 & $1-4$ chicks & $\begin{array}{l}2.15 \\
(0.51)\end{array}$ & 118 & $\begin{array}{l}1-3 \\
\text { chicks }\end{array}$ & $\begin{array}{l}3.73 \\
(0.87)\end{array}$ & 79 & 1-5 chicks \\
\hline
\end{tabular}

abreeding success excluding destroyed or unsuccessful nests (chicks per nest). 


\section{Pygmy Cormorant}

Pygmy Cormorant is a poorly known species whose distribution is restricted to southeastern Europe up to the western coast of the Caspian Sea (Crivelli et al. 200ob, Rusev and Korzyukov 2003). The Danube delta currently harbours the highest number of breeding pairs within its world distribution. From 1995 to 2001 we recorded annually between 4,000 and 8,000 breeding pairs within the Danube delta. This figure is similar to the estimate of 4,300-9,000 pairs given by Marinov and Hulea (1996) for the same period and slightly lower than that of 10,600 pairs given by Platteeuw et al. (2000-2001). In the Dnestr delta, the number of breeding pairs fluctuated from 2 to 120 pairs during the period 1975 to 1995 , then started to increase significantly in the following years with the highest figure of 900 pairs in 2001 (Figure 3). In 2000 this species also nested for the first time in the Dnepr delta with 35-40 nests and continued in 2001 with $360 \pm 35$ pairs.

The clutch sizes in the Dnestr and Danube delta were similar (Table 2). For a given year, however, breeding success was consistently higher in the Dnestr delta than in the Danube delta. Fluctuations in water levels, destruction of nests due to strong winds and food shortage might explain this difference. Breeding success at the Dnestr delta was much higher than that published for Lake Kerkini, northern Greece, though the data for the Danube delta are of the same order of magnitude (Nazirides and Papageorgiou 1996).

We consider that there were about 9,000-10,000 breeding pairs of Pygmy Cormorant from the Danube delta to the Crimean peninsula for the period 19972001. Formerly, its distribution was restricted to the Danube delta, and today it is expanding regularly to the east of the study area. This species suffers much less destruction by fishermen than Great Cormorants.

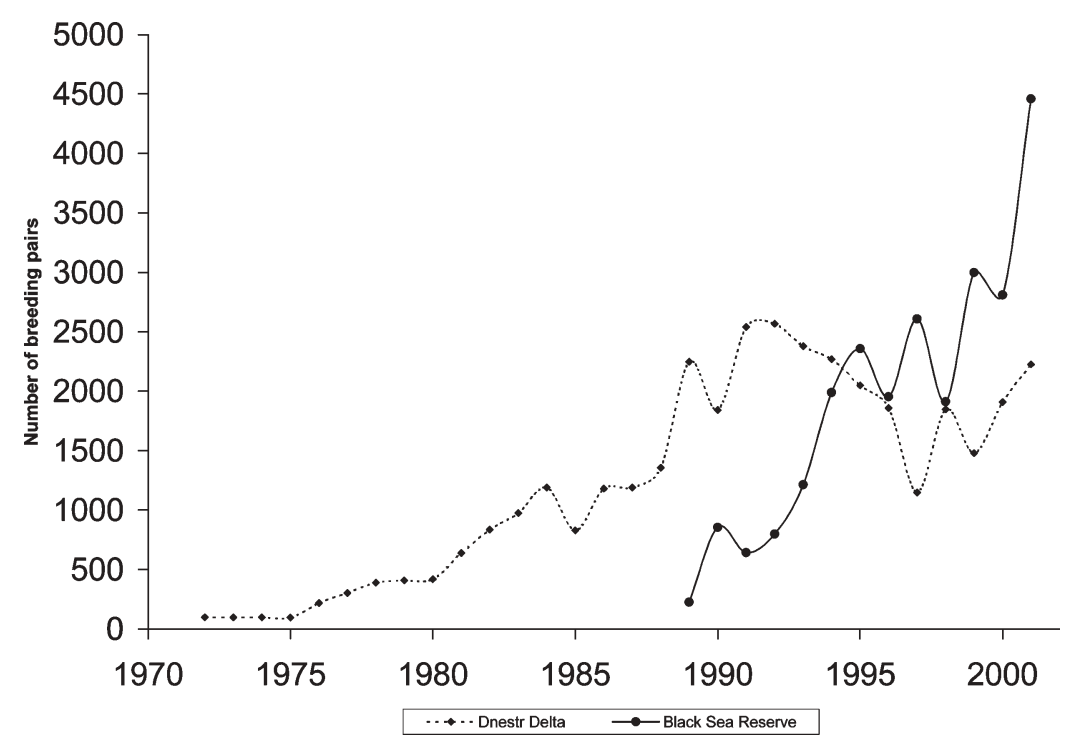

Figure 3. Trend in numbers of breeding pairs of Pygmy Cormorants in the Dnestr delta, Ukraine, 1975-2001. 
Table 2. Clutch size and breeding success (BS) of the Pygmy Cormorant in the Dnestr and Danube deltas.

\begin{tabular}{|c|c|c|c|c|c|c|c|c|c|c|c|}
\hline \multirow[t]{2}{*}{ Year } & \multicolumn{6}{|l|}{ Dnestr } & \multicolumn{5}{|l|}{ Danube } \\
\hline & $\begin{array}{l}\text { Clutch } \\
\text { size (SE) }\end{array}$ & $\begin{array}{l}\text { No. of } \\
\text { nests }\end{array}$ & Range & $\mathrm{BS}^{\mathrm{a}}$ (SE) & $\begin{array}{l}\text { No. of } \\
\text { nests }\end{array}$ & Range & $\begin{array}{l}\text { Clutch } \\
\text { size (SE) }\end{array}$ & $\begin{array}{l}\text { No. of } \\
\text { nests }\end{array}$ & Range & $\mathrm{BS}^{\mathrm{a}}(\mathrm{SE})$ & $\begin{array}{l}\text { No. of } \\
\text { nests }\end{array}$ \\
\hline 1998 & $\begin{array}{l}5.58 \\
(0.59)\end{array}$ & 77 & $\begin{array}{l}4-7 \\
\text { eggs }\end{array}$ & $\begin{array}{l}4.56 \\
(0.92)\end{array}$ & 54 & $\begin{array}{l}3-6 \\
\text { chicks }\end{array}$ & - & - & - & $\begin{array}{l}3.64 \\
(0.69)\end{array}$ & 83 \\
\hline 1999 & - & - & - & $\begin{array}{l}4.8 \\
(1.04)\end{array}$ & 70 & $\begin{array}{l}2-6 \\
\text { chicks }\end{array}$ & $\begin{array}{l}5.12 \\
(0.66)\end{array}$ & 97 & $\begin{array}{l}4-6 \\
\text { eggs }\end{array}$ & $\begin{array}{l}4.10 \\
(0.74)\end{array}$ & 79 \\
\hline 2000 & $\begin{array}{l}5.40 \\
(0.76)\end{array}$ & 48 & $\begin{array}{l}3-7 \\
\text { eggs }\end{array}$ & $\begin{array}{l}4.42 \\
(0.86)\end{array}$ & 24 & $\begin{array}{l}3-6 \\
\text { chicks }\end{array}$ & - & - & - & - & - \\
\hline 2001 & $\begin{array}{l}4.74 \\
(0.71)\end{array}$ & 141 & $\begin{array}{l}3-6 \\
\text { eggs }\end{array}$ & $\begin{array}{l}3.95 \\
(0.92)\end{array}$ & 139 & $\begin{array}{l}2-6 \\
\text { chicks }\end{array}$ & - & - & - & $\begin{array}{l}3.71 \\
(0.92)\end{array}$ & 157 \\
\hline
\end{tabular}

${ }^{a}$ Breeding success excluding destroyed or unsuccessful nests (chicks per nest).

Pygmy Cormorant is definitely associated with freshwater wetlands, while Great Cormorant is often found in brackish and saline wetlands. Pygmy Cormorant requires live trees, and is never found breeding on the ground, although sometimes it might breed within reedbeds (Crivelli et al. 20oob). In contrast, Great Cormorant can breed on dead trees, and in coastal wetlands it always breeds on the ground, often associated with gulls (e.g. Yellow-legged Gull Larus cachinans) and other species (e.g. Eider Somateria mollissima, Grey Heron Ardea cinerea, Little Egret Egretta garzetta; Rudenko and Yaremchenko 2000).

\section{Conclusion}

Breeding cormorants and pelicans within the study area were restricted in the past to the Danube delta. Today, with the exception of Dalmatian Pelican, the three other species have extended their breeding range to the east on the Black Sea coast of the Ukraine. The most successful are the two species of cormorants. The reasons behind this trend might be degraded environmental conditions within the Danube delta. However, other reasons might contribute to this expansion such as eutrophication of waters and proliferation of non-commercial cyprinids and non-commercial coastal sea fish as well as the collapse of commercial fishery, resulting in reduced disturbance and destruction of breeding colonies, though the latter can still occur in some places. The ban on culling within the Danube delta and the recent abandonment of many fish-farm facilities might also explain the observed positive trend of both species of cormorant. Cold springs with high winds might explain the observed large interannual variations of the number of breeding pairs of Great and Pygmy Cormorants. Such weather conditions delay breeding and decrease the number of breeding pairs of both species in those years.

The whole study area suffers from disturbance by birdwatchers, tourism and fishermen. Even when some areas do have protected status, the wardening and the implementation of protection measures are weak or non-existent. Especially for pelicans, disturbance is a key factor in the establishment of successful breeding colonies. We can predict that both cormorant species will continue their expansion and increase in numbers. However, Great White Pelican will probably not establish long-term breeding colonies within the Black Sea Reserve or at Lebiazi islands unless an effort for strict wardening, at least during the incubation period, is implemented. 


\section{Acknowledgements}

This work was partially funded by the Sansouire Foundation (France). We would like to thank P. Zinovij, N. Tarina, A. Grinchenko, O. Yaremchenko and G. Handrinos for their contribution at various stages of this project.

\section{References}

Ambruster, C. (1879) A visit to a breeding place of the pelican in the Danube delta of the Dobrudscha. The Zoologist 2: 243-260.

Ardamatskaya, T. B. (1994) Present status of Pelecanus onocrotalus in the Sea of Azov/ Black Sea region. Pp. 6-8 in A. J. Crivelli, V. G. Krivenko and V. G. Vinogradov, eds. Pelicans in the former USSR. IWRB Publication 27.

Catsadorakis, G. and Crivelli, A. J. (2001) Nesting habitat characteristics and breeding performance of Dalmatian pelicans in Lake Mikri Prespa, NW Greece. Waterbirds 24: 386-393.

Catsadorakis, G., Malakou, M. and Crivelli, A. J. (1996) The effects of the 1989/1990 drought on the colonial waterbirds nesting at Lake Mikri Prespa, Greece, with special emphasis on pelicans. Colon. Waterbird 19 (Special Publication I): 207-218.

Crivelli, A. J and Vizi, O. (1981) The Dalmatian pelican, Pelecanus crispus Bruch 1832, a recently world-endangered bird species. Biol. Conserv. 20: 297-310.

Crivelli, A. J., Catsadorakis, G., Jerrentrup, H., Hatzilacos, D. and Michev, T. (1991) Conservation and management of pelicans nesting in the Palearctic. Pp. 137-152 in T. Salathé, ed. Conservation of migratory birds. Cambridge, U.K.: International Council for Bird Preservation (Techn. Publ. 12).

Crivelli, A. J., Hatzilacou, D. and Catsadorakis, G. (1998) The breeding biology of the Dalmatian Pelican Pelecanus crispus. Ibis 140: 472-481.

Crivelli, A. J., Catsadorakis, G., Hatzilacou, D., Hulea, D., Malakou, M., Marinov, M., Nazirides, T., Peja, N., Sarigul, G. and Siki, M. (200oa) Status and population development of Great white pelican Pelecanus onocrotalus and Dalmatian pelican P. crispus breeding in the Palearctic. Pp. 38-45 in P. Yésou and J. Sultana, eds. Monitoring and conservation of birds, mammals and sea turtles of the Mediterranean and Black Seas. Valetta, Malta.

Crivelli, A. J., Nazirides, T., Catsadorakis, G., Hulea, D., Malakou, M., Marinov M. and Shogolev, I. (200ob) Status and population development of Pygmy Cormorant Phalacrocorax pygmeus breeding in the Palearctic. Pp. 49-6o in P. Yésou and J. Sultana, eds. Monitoring and conservation of birds, mammals and sea turtles of the Mediterranean and Black Seas. Valetta, Malta.

Keller, T. M., Carss, D. N., Helbig, A. J. and Flade, M. (eds.) (2003) Cormorants: ecology and management at the start of the 21st century. Vogelwelt 124 Suppl.: 1-400.

Lysenko, V. I. (1994) Pelecanus crispus in the Ukraine. P. 5 in A. J. Crivelli, V. G. Krivenko and V. G. Vinogradov, eds. Pelicans in the former USSR. IWRB Publication 27.

Marinov, M. and Hulea, D. (1996) Dinamica coloniilor mixte de cormorani si starci din delta Dunarii, in perioada 1989-1995. Analele Stiintifice Ale Institutului Delta Dunarii Tulcea 5: 211-226.

Mee, L. D. (1992) The Black Sea in crisis: a need for concerted international action. Ambio 21: 278-286.

Navodaru, I., Staras, M. and Cernisencu, I. (2001) The challenge of sustainable use of the Danube delta fisheries, Romania. Fisheries Management and Ecology 8: 323-332.

Nazirides, T. and Papageorgiou, N. (1996) The breeding biology of Pygmy Cormorants (Phalacrocorax pygmeus), a vulnerable bird species, at Lake Kerkini, Northern Greece. Colon. Waterbird 19 (Special Publication I): 219-223. 
Platteeuw, M., Kiss, J. B. and Sadoul, N. (2000-2001) Survey of colonial breeding birds in Romanian Danube delta, May-June 2001. Analele Stiintifice Ale Institutului Delta Dunarii Tulcea 8: 151-153.

Pringle, C., Vellidis, G., Heliotis F., Bandacu, D. and Cristofor, S. (1993) Environmental problems of the Danube delta. Am. Sci. 81: 350-361.

Rudenko, A. G. (1996) Present status of gulls and terns nesting in the Black Sea Biosphere Reserve. Colon. Waterbird 19 (Special Publication I): 4I-45.

Rudenko, A. G. and Yaremchenko, O. A. (2000) Colonial seabird monitoring in the Black Sea Biosphere Reserve (Ukraine): concept, techniques and census results. Pp. 213-220 in P. Yésou and J. Sultana, eds. Monitoring and conservation of birds, mammals and sea turtles of the Mediterranean and Black Seas. Valetta, Malta.

Rusev, I. T. and Korzyukov, I. (2003) The current status and protection of the Pygmy Cormorant Phalacrocorax pygmeus in the Ukraine. Vogelwelt 124 Suppl.: 83-86.

Schogolev, I. V. (1996) Fluctuations and trend in breeding populations of colonial waterbirds in the Dnestr delta, Ukraine, Black Sea. Colon. Waterbird 19 (Special Publication 1): 91-97.

Van Eerden, M. R. and Gregersen, J. (1995) Long-term changes in the northwest European population of Cormorants Phalacrocorax carbo sinensis. Ardea 83: 61-79.

Yaremchenko, O. A. and Rudenko, A. G. (1997) Renewal of White Pelican (Pelecanus onocrotalus) nesting in the Black Sea Biosphere Reserve. Chernivtsi 7: 42-44. (In Russian.)

\section{IGOR SCHOGOLEV}

The Goulandris Natural History Museum, Levidou Street 13, Kifissia, Greece

\section{ANTONINA RUDENKO}

Black Sea Reserve, Dneprovaya Street 26, Golaya Pristan, 75600, Kherson region, Ukraine

\section{A.J. CRIVELLI*}

Station biologique de la Tour du Valat, Le Sambuc, 13200 Arles, France

${ }^{*}$ Corresponding author

Received 2 February 2004; revision accepted 24 August 2004 